DOI: 10.46340/ephd.2021.7.3.12

Yurii Kononchuk

ORCID ID: https://orcid.org/0000-0002-8904-3634

National Pedagogical Drahomanov University, Kyiv, Ukraine

\title{
THE IMPACT OF ANTISEGREGATION MOVEMENTS ON THE CULTURAL LIFE OF AFRICAN AMERICANS IN THE 1950S AND 1960S
}

\author{
Юрій Конончук \\ Національний університет імені М. П. Драгоманова, м. Київ, Україна
}

\section{ВПЛИВ АНТИСЕГРЕГАЦІЙНИХ РУХІВ НА КУЛЬТУРНЕ ЖИТТЯ АФРОАМЕРИКАНЦІВ У 1950-1960-X РОКАХ.}

The struggle of African Americans for their civil rights is a long historical process that occupies a significant place in the history of the United States. The period of 1950-1960 was a turning point. The movement was led and organized by Martin Luther King. The structuring of the movement, the formation of its ideological basis, and specific political goals had a positive effect on the quality and speed of social change. Achieving the main goals of the movement has affected the entire public life of the United States. One of the consequences of the influence was the transformation of the cultural life of African Americans. The situation with the participation of African Americans and their reflection in culture has shown positive dynamics since the end of the XIX century. Cultural phenomena have always been closely linked to socio-political life. Music and cinema have become areas of new opportunity for self-realization for African-American artists. The middle of the twentieth century was the culmination of the civil rights movement. Violent and non-violent movements, numerous rallies, boycotts, and marches were widely reflected in the culture of the period.

The article raises a number of issues related to the development of African American culture, the regularity of cultural processes, the relationship between political movements, and their impact on cultural phenomena. Particular attention is paid to the field of literature and drama because this area has always been a tool for reflecting certain aspects of social reality for Americans. We also attempted to analyze the impact of the movement on fashion, music, and symbolism in culture in general. The consequences of innovations in the field of culture, their significance for their further development are studied. An attempt is made to highlight the changing role of art after the formation of mass culture and the development of television.

Keywords: mass culture, civil rights, African Americans, M.L. King, Malcolm X, literature, music, fashion, drama, poetry, Nina Simone, J. Brown, Sam Cook, Amiri Baraka.

Виклад основного матеріалу. Кульмінаційний момент антисегрегаційних рухів 60 -х років XX століття - прийняття закону про громадянські права - не поставив остаточну крапку у правозахисних процесах. Він був підписаний 19 червня 1964 року президентом Ліндоном Джонсоном. Останній закликав американців «об'єднатися у цій спробі принести справедливість і надію усьому нашому народу» ${ }^{1}$. Попереду ще було тривале продовження боротьби проти сегрегації, майже щорічне прийняття супровідних у таких процесах законів, а головне імплементації результатів законодавчої діяльності на місцях, робота із громадськістю та із суспільною думкою.

Таке глобальне для американського суспільства явище, як рух афроамериканців за свої громадянські права, не могло не знайти відображення у культурних процесах того часу. Культура, слугуючи мірилом суспільної прогресії, завжди відображала внутрішньо важливі процеси. Як зазначалось у цьому дослідженні вище, ще у XIX столітті з'являлися елементи культурного

${ }^{1}$ Римини, Р. (2018). Краткая история США. Москва: КоЛибри, Азбука-Аттикус, 368. 
відображення життя та політичного положення темношкірого населення США. Розвиваючись одночасно із загальноамериканською культурою, культура афроамериканців стала їі невід'ємною частиною, формуючи соціально важливий інформаційний блок. Із становленням феномену масової культури, значення афроамериканської творчості та мистецтва, яке висвітлювало питання пов'язані із афроамериканцями різко зросло. Ці прояви мистецтва стали елементом формування громадської думки. Вони демонстрували існування афроамериканської культури і проявляли намір зайняти їхнє законне місце у культурному життя США та інформаційному полі суспільства.

Значення культури розумів і Мартін Лютер Кінг. У червні 1955 р. він обійняв посаду пастора баптистської церкви в Монтгомері, штат Алабама. Опинившись у неофіційній «столиці» південноамериканського расизму, доктор Кінг намагався організувати темношкіру спільноту у ефективно працюючу організацію, яка могла б просувати свої ідеї і, водночас, захищати їі учасників. Серед своїх перших кроків на цьому напрямку, новий проповідник організував у своїй парафії цілий ряд комітетів, а саме: комітет соціального забезпечення для допомоги хворим і нужденним, комітет релігійного виховання, комітет з розподілу стипендій та грантів серед випускників середньої школи. Також було створено соціально-політичний комітет, головними завданнями якого стали організація зустрічей, залучення членів приходу до діяльності «Національної асоціації сприяння прогресу кольорового населення», ведення Фондом обліку і контролю за реєстрацією виборців, а також «інформування прихожан про суспільно-політичну та економічну ситуацію». Поміж усіх інших, було створено комітет культури. Він був повинен займатися збереженням автохтонних ідей темношкірої спільноти, популяризувати їхню культуру та сприяти залученню молоді до мистецьких рухів. ${ }^{1}$

Відображення процесів боротьби проти расизму умасовій культурі пов'язане не лише із висвітленням іiі причин, подій та наслідків. Особливе місце у цій суспільній взаємодії займають індивідуальності - відомі митці, які прямо чи опосередковано долучилися до руху за громадянські права. Оскільки, антисегрегаційний рух середини XX століття у США був чи не головним суспільнополітичним явищем, то плеяда залучених творців: музикантів, літераторів, кінематографістів - $€$ надзвичайно широкою.

Першим варто згадати Сема Кука (Sam Cooke). Він був класичним афроамериканським співаком, який починав із церковної діяльності у стилі госпел, але у 1957 році змінив свій вектор розвитку на поп-музику. Він став, разом із Реєм Чарльзом, одним із найвпливовіших темношкірих музикантів післявоєнної Америки ${ }^{2}$. Його пісня «Change is gonna come» була сповнена оптимізму щодо розширення кордонів. Вона була популярною серед учасників руху. Співаючи про надію, яка обов'язково прийде, він стверджував надію на успіх серед демонстрантів ${ }^{3}$.

Джазова виконавиця та піаністка Ніна Сімоне висловлювала свою опозицію зверхності білих. Почавши кар'єру у 1954 році, вже на початку 60-х років вона долучається до протестних рухів. Починає дружити із Мартіном Лютером Кінгом, Малкольмом Іксом. Ніна Симоне виступає на демонстраціях. Підсилюючи національну самоідентифікацію, вона починає додавати елементи народної культури афроамериканців та госпелу до своєї музичної творчості ${ }^{4}$. Особливої уваги заслуговує її творчість 1964 року, апогеєм якої стала пісня «Mississippi goddamn». Ї̈ї написання було спричинене актами насильства щодо учасників правозахисних рухів: вибухом у церкві у місті Бірмінгем та вбивством Медгара Еверса, ветерана Другої світової та активного учасника руху за громадянські права. Тематиці боротьби за рівні права, за соціальну справедливість присвячено

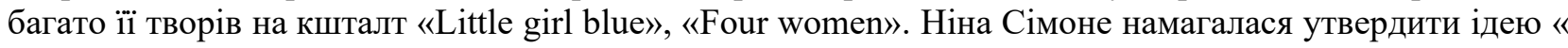
Ми-сильні», намагалися здійснити форматування афроамериканської ідеї, мотивувати учасників руху не 3 позицій жертви та подальшої жертовності, а з позицій внутрішньої сили та значимості, власного самоствердження у американському суспільстві ${ }^{5}$.

\footnotetext{
${ }^{1}$ Джонсон, Р. (2000). Мартин Лютер Кинг-младший и ненасильственная борьба за гражданские права в Америке. «Ненасилие как мировоззрение и образ жизни». Сборник статей, 27.

${ }^{2}$ Ritz, D. (2021). Sam Cook. Encyclopedia Britannica <https://www.britannica.com/biography/Sam-Cooke> (2021, травень, 27).

${ }^{3}$ The Civil Rights Movement: A Cultural Revolution (2014). Documentaries

$<$ https://www.memphis.edu/benhooks/documentaries/aculturalrevolution.php>. (2021, травень, 28).

${ }^{4}$ Encyclopedia Britannica ( 2021). Nina Simone <https://www.britannica.com/biography/Nina-Simone>

(2021, травень, 27).

${ }^{5}$ The Civil Rights Movement: A Cultural Revolution (2014). Documentaries

<https://www.memphis.edu/benhooks/documentaries/aculturalrevolution.php>. (2021, травень, 28).
} 
Схожі із Ніною Сімоне позиції займав співак Джеймс Браун. У 1968 році він сказав: «Я чорний і я пишаюсь цим!». Його світоглядні позиції здійснили значний вплив на покоління молодих афроамериканців, яке підростало у 70-80-х роках. Джеймс Браун остаточно дав зрозуміти, що афроамериканці отримали рівність, що означало вільний і відкритий доступ до освіти та роботи. «Я не хочу знати про це - це мені нічого не дає. Лише відкрийте двері - саме це і потрібно. Я все зроблю сам» ${ }^{1}$.

Ідеї Ніни Сімоне знаходили активний відгук серед учасників руху, оскільки були їм близькими та відповідали раціональності методології їхньої боротьби. Одним зі способів ненасильницького самоствердження для афроамериканців став їх зовнішній вигляд. Одяг та його атрибутика стала першою відмінною зовнішньою рисою для демонстрантів. Виходячи на мітинги, вони старались одягатися демонстративно витончено. Одяг завжди був чистим, якісним, гарно підібраним. Сукні, блузи, спідниці для жінок, костюми, туфлі, жилетки та капелюхи для чоловіків. Одяг супроводжувався обов'язковими аксесуарами: годинниками, коштовними прикрасами, запонками тощо. Досить швидко ці ідеї набули поширення і в побутовому житті. Мирний охайно одягнений афроамериканець став своєрідною «візитівкою руху». Метою такого переодягання була боротьба iз расистськими стереотипами про те, що темношкіре населення «брудне», «дике», «нецивілізоване» і не $\epsilon$ рівнею білій привілейованій спільноті. Президент Національного музею Руху за громадянські права Беверлі Робертс дає цим явищам наступну оцінку: «Люди, що були залучені до руху за громадянські права, хотіли бути впевненими, що вони достатньо демонстративні, і шлях, яким вони це робили, було одягання у костюми із краваткою»².

Сталість процесів боротьби, успіхи у протистояння із державним насиллям та протидією, невдачі білих радикальних опонентів з їхніми терористичними методами - стверджували віру афроамериканців в успіх своїх починань. Позитивний досвід використання атрибутів зовнішнього вигляду, стимулював темношкіру спільноту продовжувати рух у даному напрямку. Після закріплення своїх успіхів та посилення культурних рухів, афроамериканці почали застосовувати у формуванні свого зовнішнього вигляду африканські елементи. Це сприяло їхній етнічній самоідентифікації та ствердженню їхньої спільноти у американському суспільстві, як окремої та рівноправної. Особливо популярними запозиченнями із африканської культури стали зачіски та одяг. Афроамериканці, які долучалися до цієї тенденційної течії, демонстрували, що вони приймають своє африканське минуле, не соромляться його. Таким чином, мода стала інструментом візуальної комунікації. Одяг та головні убори носили узагальнене стилістичне найменування «kente». Кенте - це текстиль ручного виробництва, 3 шовку та бавовни, який вироблявся у Гані та Сенегалі. У минулому він використовувався лише для одягання місцевих королів, їхньої сім'ї та найближчого оточення. Тепер він набув символічного значення. Його яскраве полотно, із різнокольоровими пістрявими барвами символізувало усю діалектичну та етнічну різноманітність Африки, а за нових умов - поєднання різних національних груп у одному суспільстві. Особливого розмаху вищевказані суспільні явища набудуть у другій половині $60-\mathrm{x}^{3}$.

Паралельно із прийняттям та поширенням африканських мотивів серед учасників руху, відбувався процес ще однієї культурної сепарації, що мали на меті продемонструвати силу афроамериканської спільноти. У місті Окленд, штат Каліфорнія було проведено офіційний захід у форматі вечірки, присвячений пам'яті Малкольма Ікса, якого було вбито 21 лютого 1965 року. Фундатором заходу була місцева організація Чорних пантер. Названа організація презентувала більш радикальне крило руху за громадянські права. Ї̈̈ дії та акції носили більш різкий та демонстративний характер. Зокрема, продовжуючи розкривати ефективність використання зовнішньої атрибутики у процесах боротьби, вони реалізували власне бачення цього методу. На вищезгаданій вечірці Чорні пантери вперше з'явилися у своєму, уже традиційному, вигляді - чорні шкіряні жакети чи куртки та чорні шкіряні штани. Опираючись на візуальне сприйняття стереотипних уявлень, вони прагнули продемонструвати численність, організованість та силу своєї організації, та й афроамериканців загалом. Таке використання уже перевірених раніше прийомів перетворило їхній одяг на упізнаваний символ. Стилістика одягу цієї організації перегукувалася із ії̈ назвою. В обох випадках закладався той самий символізм - чорний, сильний, природній ${ }^{4}$.

\footnotetext{
${ }^{1}$ The Civil Rights Movement: A Cultural Revolution (2014). Documentaries

<https://www.memphis.edu/benhooks/documentaries/aculturalrevolution.php>. (2021, травень, 28).

2 Там само.

${ }^{3}$ Там само.

${ }^{4}$ Там само.
} 
Прив'язка стилізованої акції Чорних пантер до постаті Малкольма Ікса не була випадковою. Останній ще з моменту виникнення тенденції зрозумів ії майбутню роль. М. Ікс був відомий не лише своєю письменницькою та громадською роботами, він також володів своїм витонченим упізнаваним стилем. Зазвичай він був одягнений наступним чином: офіційний костюм чорного або темного кольору, облягаючого покрою; метелик або однотонна краватка. М. Ікс уникав смужок, малюнків чи яскравих кольорів при виборі одягу. Радикальність його ідей, рішучість та наполегливість його діяльності гармонійно доповнювались його стриманим, але різким візуальним образом. Він став представницьким зображенням Нації ісламу. Витонченість та простота символізували цілеспрямовану силу ${ }^{1}$.

Ще однією історичною особистістю, яка стала «живим» символом громадянських рухів була Анжела Девіс (Angela Davis). Вона народилася у 1944 році, у штаті Алабама, у сім’ї вчителів. Провівши дитинство у сегрегованому оточенні, вона стала активним борцем за права людей. Анжела Девіс долучалась до руху за права жінок, піднімала питання економічної рівності та соціальної справедливості i, однозначно, не могла пройти повз громадянські рухи афроамериканців, пік яких припав на ії молодість ${ }^{2}$. Зайнявши позицію активного суспільного діяча, вона приєднувалася до багатьох тогочасних груп та організацій. Серед них варто відмітити комуністичну партію США та Чорних пантер. Енергійна діяльність Анжели Девіс гармонійно доповнювалась її класичною зачіскою «афро». Остання набувала популярності в 60-х роках, як символ бунтарства. Анжела Девіс стала образом свободи і їі зачіска, як невід’ємний компонент - теж³.

Використання зовнішньої атрибутики учасниками руху за громадянські права однозначно не було єдиним методом ненасильницької боротьби. Їхнє використання свідчить про те, що методологія афроамериканських протестів була всеохопною і не нехтувала жодним із законних мирних методів. Прийняття усіх цих зовнішніх атрибутів білими учасниками руху, що приходили на мітинги, демонструвало усім, що і білі, і темношкірі можуть діяти разом, співіснувати разом, і вони не бояться цього показувати. Саме цей аспект руху за громадянські права буде поширений на протест проти В'єтнамської війни. Там матиме місце цілий ряд запозичень, на кшталт, відображення у фільмах і по телебаченню, літературна та пісенна творчість, використання символізму одягу, як ознаки єдності. Тільки у тому випадку, символом стане не костюм із краваткою, а джинсовий одяг із численними нашивками. Усі ці рухи та протести дали суспільству та державі чітке розуміння того, що будь-яке мистецтво можна використати у якості гучномовця ${ }^{4}$.

Продовженням попередніх культурних процесів стало літературне життя середини століття. Як і раніше, літературна творчість афроамериканців була тісно пов'язана із десегрегаційними ідеями та процесами та старалася відображати реальне положення темношкірого населення у США. Літератори середини століття, які стали свідками переломного моменту у процесах боротьби за громадянські права, залишалися вірним літературним традиціям минулих авторів. У значній мірі, це було спричинено тенденціями розвитку самої американської літератури.

Сполучені Штати Америки протягом своєї історії постійно закріплювали образ індивідуальності, окремої особистості, як провідної сили кожної епохи. Початок цієї ідеї лежить у пуританській ідеологія, яка успішно поєднувала «протестантську етику і дух капіталізму». Розвиток ця думка отримала у філософії трансценденталізму, головній системі ідеологічних понять Америки у XIX столітті. Наступною ланкою еволюції філософських ідей став романтизм, який через схильність американців до асиміляції та поєднання із автохтонними елементами, також був знаковим i неповторним для історії світової літератури. У ньому поєднувалися ідеї сили окремого індивіда та сакралізація машинного виробництва. Саме в силу ментальної специфіки культура США мала джерела для постійного поповнення художньої сфери 5 . Т. Денисова, як приклад, визначала наступні культурні та суспільні явища: Негритянський ренесанс, Південний ренесанс - художні явища, які виникли у міжвоєнний період із раніше маргіналізованих територій ${ }^{6}$. «Негритянський ренесанс»-

\footnotetext{
${ }^{1}$ The Civil Rights Movement: A Cultural Revolution (2014). Documentaries

$<$ https://www.memphis.edu/benhooks/documentaries/aculturalrevolution.php>. (2021, травень, 28).

${ }^{2}$ Encyclopedia Britannica (2021). Angela Davis <https://www.britannica.com/biography/Angela-Davis>. (2021, травень, 27).

${ }^{3}$ The Civil Rights Movement: A Cultural Revolution (2014). Documentaries

$<$ https://www.memphis.edu/benhooks/documentaries/aculturalrevolution.php>. (2021, травень, 28).

${ }^{4}$ Там само.

5 Денисова, Т. Н. ( 2012). Історія американської літератури. Київ: ВД «Києво-Могилянська академія», 87-88.

${ }^{6}$ там само, 89.
} 
це афроамериканське відродження автохтонної літератури, яке було наповнене неповторною специфікою, яка базувалась на расовому, історичному, естетичному та психологічному досвіді ${ }^{1}$. Неминуче піднесення афроамериканської літератури та культури загалом передбачав Вільям Дюбуа (William Du Bois) (1868-1963). Він був істориком, соціологом та письменником. Дослідники називали його найбільш важливим лідером афроамериканських протестів першої половини XX століття. У нього був великий творчий доробок, який тематично охоплював соціологію та історію темношкірого населення у XIX столітті, але його головним твором є збірка есе «Душа культури темношкірих» ( «The Souls Of Black Folk»), яка була опублікована у 1903 р. У ній Дю Буа закидав, що стратегія уряду США, замість того, щоб звільнити афроамериканців від гноблення, створює умови для його продовження. Саме у цій роботі, Вільям Дюбуа, висуває свою теорію ментального дуалізму темношкірих американців ${ }^{2}$. Він стверджував, що афроамериканці від народження наділені «twoness» - роздвоєною свідомістю, яка допомагала їм соціалізуватися в сегрегованому суспільстві. Взаємодіяти окремо зі своєю спільнотою, і окремо із суспільством та державними структурами. Співіснувати відразу у двох культурних та ідеологічних середовищах. Це позитивно вплине на процеси становлення та участі афроамериканських літераторів у другій половині XX століття, оскільки названа ідея стане провідною для тогочасної постмодерністської літератури ${ }^{3}$.

Окрему категорію літератури становлять твори провідних ідеологів руху за громадянські права, які водночас були його провідниками та безпосередніми учасниками. Серед названих, провідними $\epsilon$ апологети насильницького та ненасильницького напрямів боротьби - Мартіна Лютера Кінга та Малкольма Ікса.

Першим твором М. Л. Кінга, який отримав широке розповсюдження і здійснив вплив на суспільну свідомість у контексті формування ідеології масової культури, був «Лист із Бірмінгемської в'язниці» («Letter from Birmingham Jail») надрукований у 1963 році. У квітні 1963 року, М. Л. Кінга було заарештовано, як одного із організаторів «сидячого протесту». Лист був написаний безпосередньо під час перебування у тюрмі. Провідною темою твору несправедливість системи по відношенню до афроамериканців загалом та демонстрантів зокрема. Він акцентує увагу на несправедливості судів, жорстокості поліцейських, називає Бірмінгем «найбільш сегрегованим містом». Також у своєму листі пастор виступає із критикою своїх опонентів, які виступають проти активних дій на вулицях, вважаючи що марші, протести і демонстрації лише ескалюють конфлікт, а усі протиріччя потрібно вирішувати у судах. Кінг же, у свою чергу, наполягає на ефективності ненасильницького протесту і вказує, що їхня мета «підтримання здорової напруги у суспільстві», яка актуалізує проблеми темношкірих та стимулює уряд та місцеву владу ${ }^{4}$.

Ідеї закладені у «Листі із Бірмінгемської в'язниці», М. Л. Кінг продовжує розвивати у своєму наступному творі «Чому ми не можемо чекати»(«Why We Can’t Wait»). Написання цієї книги розпочалося восени 1963 року, після успіху попередньої публікації. У роботі йому допомагали два його помічники Кларенс Джонс (Clarence Jones) та Стенлі Левісон (Stanley Levison). Саме у цій праці М. Л. Кінг дає вичерпне пояснення терміну «Негритянська революція» («Negro Revolution»), який він увів до обігу у своїх попередніх роботах. 3 метою його пояснення він зображує історію гноблення темношкірих у минулого, елементи несправедливості, які збереглися до сьогодні та поточні політичні обставини, які підсилюють фрустраційні настрої серед афроамериканського населення США. Вказує на повільну імплементацію юридичних рішень та нехтування громадянськими правами кольорового населення з боку обох політичних партій. Також він акцентував увагу на тому, що звільнення людей Африки(деколонізації африканських країн у 50-х - 60-х роках XX ст.), відбувалось швидше, ніж десегрегація афроамериканців у США. Ще одним аргументом на користь негайності дій та рішень було апелювання до прокламації президента США Авраама Лінкольна: «століття емансипації дала негру привід діяти - причину настільки просту і очевидну, що йому потрібно зробити крок назад, щоб ії побачити» 5 .

\footnotetext{
1 Денисова, Т. Н. ( 2012). Історія американської літератури. Київ: ВД «Києво-Могилянська академія», 90.

${ }^{2}$ Rudwick, E. (2021). W.E.B. Du Bois. Encyclopedia Britannica, 23 Feb. 2021.

<https://www.britannica.com/biography/W-E-B-Du-Bois>. (2021, травень, 27).

${ }^{3}$ Денисова, Т. Н. ( 2012) Історія американської літератури Київ: ВД «Києво-Могилянська академія», 93.

${ }^{4}$ King, M. L. Jr. (1963). Letter from Birmingham Jail

<https://www.africa.upenn.edu/Articles_Gen/Letter_Birmingham.html>. (2021, травень, 27).

${ }^{5}$ King, M. L. Jr. (1964). Why We Can't Wait <https://kinginstitute.stanford.edu/encyclopedia/why-we-cant-wait>. (2021, травень, 27).
} 
Кілька розділів були присвячені ресурсам та зусиллям, які були витрачені на «ненасильницький хрестовий похід 1963». Книга була опублікована у червні 1964 року, видавництвом «Harper \& Row». Книга було добре сприйнята суспільством, рецензенти хвалили книгу як «прямолінійну книгу, яку повинні прочитати обидві раси», i «одне з найбільш красномовних досягнень року - насправді будьякого року» ${ }^{1}$.

Малкольм Ікс також був активним борцем за права афроамериканців, хоч і стояв на відмінних від М. Л. Кінга позиціях. Як і в останнього, методами його участі в масовій культурі були інтерв’ю, живі виступи у клубах та на демонстраціях, громадська діяльність та написання статей. Головним літературним спадком Малкольма Ікса вважається його автобіографія («The Autobiography of Malcolm Х». Він іiі написав у співавторстві із Алексом Гейлі, вона була опублікована у 1965 році. Автобіографія розповідає про життя Малкольма від його травматичного дитинства, наповненого расизмом, далі охоплює період його нелегальної діяльності (наркоторгівля та сутенерство). Наступним $\epsilon$ етап його переходу до віри, як мусульманина-афроамериканця(вступ до Нації ісламу), перебування у в'язниці за крадіжку. Потім описуються роки активної громадянської діяльності, описується ідеологічні засади його світоглядної позиції. Остання частина книги присвячена його наверненням до ортодоксального ісламуㄹ․

У післявоєнні роки, поділ американської літератури на ідейно-естетичні течії різного спрямування став ще більш підкресленим. У 1940-70х роках все ще доволі високим залишався запит на літературну реакцію: відображення і висвітлення у культурі актуальних соціальних питань у ії значимих проявах. Ще однією рисою післявоєнних десятиліть було те, що це був, по суті, останній етап художньої творчості прозаїків, поетів і драматургів старшого покоління, які формувалися та творили у добу класичного модернізму.

Міграційні процеси першої половини XX століття сприяли формуванню міського аспекту розвитку афроамериканської культури. Культурні процеси та явища, які мали місце раніше, знову переживали піднесення викликане рухом за громадянські права. Планомірне підняття расового питання та поступове зростання його актуальності, разом із посиленням викликаної ним соціальної напруги спричинили активізацію літературного життя темношкірої спільноти. Тісний взаємозв'язок між літературною діяльністю темношкірих митців і рухом за громадянські права помітний у 1940-х, 1950-х та особливо у 1960-х. Як і решта активістів-афроамериканців, вони намагалися пришвидшити падіння расових упереджень, здолати сегрегацію та надати нового значення поняттю «націоналізм темношкірих». Висвітлюючи названі процеси та дотичні до них теми, автори середини століття здійснювали спробу поширювати ці інформаційні меседжі у своїх творах.

Одним із перших авторів, який почав реалізовувати вищезгадані ідеї став Річард Райт (Richard Wright). Річард Райт (1908-1960) був вихідцем із родини колишніх рабів . Літературна кар'єра його пішла вгору у 1938 році, завдяки роману «Діти дядька Тома» («Uncle Tom`s children»). Провідною ідеєю твору було запитання скільки всього афроамериканців проживає у країні, яка їх дегуманізує? Головною його працею був роман «Native son», який розповідав про Біггера Томаса, молодого темношкірого хлопця і його проблеми із входженням до американського суспільства. Соціальним фоном для твору слугує місто Чикаго. Роман став бестселером і, навіть був поставлений на Бродвеї самим Орсоном Уелсом. Останнє свідчить про посилення значення афроамериканців у культурних процесах США. Активна творча діяльність у період Другої світової війни та повоєнні роки зробили Р. Райта взірцем для афроамериканської літературної спільноти ${ }^{3}$.

Ідейним продовжувачем творчості Річарда Райта став його друг Джеймс Болдуін (1924-1987) (James Baldwin). Дж. Болдуін називав Р. Райта «найвидатнішим чорним письменником у світі для мене». У своїх працях Дж. Болдуін піднімав питання раси та сексуальності. Д. Болдуін писав глибоко особисті історії про те, як це бути одночасно і темношкірим, і гомосексуалістом, у часи, коли жодна із його ідентичностей не приймалась американським суспільством. У 1957 році він долучився до боротьби за громадянські права. У цей період вийде дві його книги присвячені безпосередньо цим подіям: «Ніхто не знає мого імені» («Nobody Knows My Name») та « Iнша країна» («Another Country»).

\footnotetext{
${ }^{1}$ King, M. L. Jr. (1964). Why We Can't Wait <https://kinginstitute.stanford.edu/encyclopedia/why-we-cant-wait>. (2021, травень, 27).

${ }^{2}$ Encyclopedia Britannica (2021). The Autobiography of Malcolm X <https://www.britannica.com/topic/

The-Autobiography-of-Malcolm-X>. (2021, травень, 27).

${ }^{3}$ Encyclopedia Britannica (2021). Richard Wright <https://www.britannica.com/biography/Richard-Wright-American-writer > (2021, травень, 27).
} 
Збірка есе «Ніхто не знає мого імені» була опублікована у 1961 році. Вона висвітлювала відносини між білими та темношкірими жителями Сполучених Штатів. Ця тема також залишилась провідною у його наступному творі «Інша країна». Роман побачив світ у 1962 році, він досліджує проблеми породжені не лише расовими протиріччями, а й упередженим ставленням до представників гомосексуальної спільноти ${ }^{1}$.

Ще одним письменником, якого підштовхнув до творчості Річард Райт був Ральф Елісон(Ralph Ellison). За життя він опублікував один роман, який зробив його популярним. У 1953 році вийшов друком «Людина-невидимка» («Invisible Man»). У тому ж році він виграв номінацію книга року. Історія темношкірої молоді, що з Півдня їде у Гарлем і приєднується до боротьби 3 тиском привілейованої білої спільноти, написана у стилі «більдунгроман» («bildungsroman»). Цей німецький жанр літературного твору, характеризується своєю освітньою та моралізаторською роллю. Герой(доволі часто безіменний, герой-дзеркало) проходячи через вибрані автором обставини, переживає моральну перебудову, еволюцію світоглядних позицій. «Людина-невидимка» стала провідником нової афроамериканської культурної ідентичності. У 1964 році Р. Елісон опублікував свою передостанню прижиттєву книгу, збірку есе «Тінь і дія»(« Shadow and Act»). Іншим важливим аспектом діяльності Р. Елісона, крім літературної, була просвітницька. Після успіху свого роману він їздив із лекціями по всій Америці. У своїх виступах він розповідав про культуру афроамериканців, їхній фольклор та творче письмо. Зазвичай його слухачами були студенти американських коледжів та університетів. Він зробив знаковий внесок у популяризації афроамериканської культури, сприяв її становленню у тогочасній масовій культурі ${ }^{2}$.

Недооціненим аспектом американської культури того періоду є творчість афроамериканських поетес. Серед останніх варто відмітити Гвендолін Брукс (Gwendolyn Brooks). Г. Брукс (1917-2000) присвятила свою творчість життю темношкірих у містах, їхній соціалізації та повсякденних проблемах в умовах геттоїзації міст. Ї̈̈ літературний дебют відбувся у 1945 році зі збіркою «Вулиця Бронзевілля» («A Street in Bronzeville»). Вона стала першою афро-американською поетесою, яка виграла Пулітцерівську премію (1950). Ї̈̈ було нагороджено за їі другу збірку «Енні Аллен» («Annie Allen») випущену у 1949 році. Це видання являло собою серію поем присвячених зростанню дівчатафроамериканок утогочасному Чикаго. У 1953 році, ця ж тематика знову буде піднята авторкою у романі «Мод Марта» («Maud Martha»). Прямою рецепцією руху за громадянські права стала збірка «У Мецці»(« In the Месса»). Половина книги це поеми про людей у Мецці. Інша половина книги містить поеми індивідуального присвячення, найбільш знакові серед них це «Хлопець, що розбивав скло» та «Малкольм Ікс». Також Г. Брукс написала ряд книг для дітей та автобіографію у двох томах. Успіхи Гвендолін Брукс у культурній сфері надихали інших темношкірих жінок на активізацію своєї участі у культурних процесах. Зокрема, майже одночасно із Г. Брукс упоетичному життя літературної Америки 50-60-х років зростала популярність та значимість Ніккі Джованні (Nikki Giovanni) та Соні Санчез (Sonia Sanchez) ${ }^{3}$.

Лорейн Хансберрі(Lorraine Hansberry) також була уродженкою міста Чикаго. Вона прожила всього 35 років (1930-1965), і померла від раку на піці своєї кар'єри. На відміну від вищезгаданих митців, вона представляла афроамериканську спільноту у жанрі драматургії. У 1958 році ій вдалося спродюсувати ii п'єсу «A Raisin in the Sun». Вона вдало дебютувала на Бродвеї у 1959 році. Ïї постановником був актор Ллойд Річардс (Lloyd Richards). Він був першим афроамериканцем якого допустили до режисури на Бродвеї із 1907 року. Така подія була однозначним відгуком на суспільнополітичні рухи, що охопили в той час Сполучені Штати - вперше за останні 50 років на «білому» Бродвеї була поставлена п'єса про життя афроамериканців, зрежисована афроамериканцем та написана афроамериканкою. Їхня постановка виграла Премію критиків Нью-Йорка. Тематично п'єса висвітлювала бідну сім'ю афроамериканців, представників робітничого класу, які жили у Чикаго. У 1961 році їі було екранізовано і вона виграла приз Канського кінофестивалю. Не менш соціально гострою була і наступна п’єса Л. Хансберрі «Знак у вікні Сідні Брюстейн» («The Sign in Sidney Brustein's Window»). Це була драма яка піднімала політичні та соціальні питання у провінційному

\footnotetext{
${ }^{1}$ Encyclopedia Britannica (2021). James Baldwin <https://www.britannica.com/biography/James-Baldwin>. (2021, травень, 27).

${ }^{2}$ Encyclopedia Britannica (2021). Ralph Ellison <https://www.britannica.com/biography/Ralph-Ellison>. (2021, травень, 27).

${ }^{3}$ Encyclopedia Britannica (2021). Gwendolyn Brooks <https://www.britannica.com/biography/Gwendolyn-Brooks>. (2021, травень, 27).
} 
містечку Грінвіч. На Бродвеї вона була поставлена у 1964 році. У ній уже чітко відображались зміни, які спіткали рух за громадянські права: взаємна праця білих і темношкірих громадян, відсутність сепарації на побутовому рівні, відображення спільності побутових та суспільних проблем для обох етнічних груп ${ }^{1}$.

Амірі Барака (Amiri Baraka), справжнє ім'я Еверетт Лерой Джонс (Everett Leroy Jones) був доволі одіозним діячем у сфері культури. Письменник та драматург усе життя (1934-2014) прожив у штаті Нью-Джерсі. Він публікував провокативні матеріали на тему зверхності білого населення та придушеного, стриманого гніву, що існував у темношкірій спільноті. На противагу пізній творчості Л. Хансберрі, Еверетт Джонс також зображував співжиття білих та темношкірих американців, але у його п’єсі «Голандець» («Dutchman») це призводило до протистояння, а у фіналі до трагедії, вина за яку лягала на білу жінку. П’єса була поставлена у 1964 році у (1967 році була екранізована). Після убивства Малкольма Ікса, Еверетт зосередився на Чорному націоналізмі. Він покинув дружину, переїхав у Гарлем де відкрив «Black Arts Repertory Theatre». У 1968 році, він бере собі псевдонім Амірі Барака. Намагаючись ствердити афроамериканську культуру, А. Барака працював відразу у багатьох сферах. Він був поетом, драматургом, видавцем книг, написав історію афроамериканської музики, працював у Йельському та Нью-йоркському університетах, у якості спеціаліста з Африки. У середині 70-з років XX століття Амірі Барака написав: «Я бачу мистецтво як зброю, зброю революції». Гостро усвідомлюючи проблематику національних питань, він прагнув діяти за допомогою сфери масової культури, значення якої також розумів ${ }^{2}$.

У 1957 році був опублікований комікс написаний Альфредом Хаслером (Alfred Hassler) i Бентоном Ресніком (Benton Resnik). Його ілюстратором був Ci Беррі (Sy Barry). Головним сподвижником його появи було Товариство примирення («Fellowship of Reconciliation»). Ця антисегрегаційна організація, яка стояла на позиція ненасильства та просвітницької роботи. Оскільки, комікс був проігнорований дистриб'юторським крилом комікс-індустрії, то його поширення відбувалося власними силами причетних афроамериканців та небайдужих осіб. Його поширювали угрупах із захисту громадянських прав, школах, церквах. Було надруковано 250000 примірників англійською та 125000 примірників іспанською. Пізніше була створена ще арабська версія. Поширення комікса вийшло за межі США, і примірники графічного твору досягли Африки, Південної Америки, Близького Сходу та деяких інших регіонів світу. В основі сюжету лежала історії Рози Паркс і автобусного протесту у місті Монтгомері у 1955 році. Головним героєм твору виступав Мартін Лютер Кінг

Висновок. Отже, боротьба за громадянські права трансформувала американців та американську культуру. Ця трансформація мала місце протягом усіх фундаментальних політичних, соціальних і культурних змін епохи. Адвокати расової рівності просували «бунт», як філософське поняття і спосіб досягнення спільних цілей. Їхні зусилля були об'єднані у вірі, що дві нації, за умов, коли одна страждає від утисків, а інша вільна - не можуть співіснувати.

\section{References:}

1. Dzhonson, R. (2000). Martyn Liuter Kynh-mladshyi y nenasylstvennaia borba za hrazhdanskye prava v Ameryke. [ Martin Luther King Jr. and the Nonviolent Struggle for Civil Rights in America]. Nenasylye kak myrovozzrenye y obraz zhyzny. Sbornyk statei [Nonviolence as a worldview and way of life. Digest of articles]. [in Russian].

2. Ritz, D. (2021). "Sam Cooke". Encyclopedia Britannica <https://www.britannica.com/biography/Sam-Cooke. (2021, May, 27). [in English].

3. Rymyny, R. (2018). Kratkaia ystoryia SShA [The short history of the US]. Moscow: KoLybry, Azbuka-Attykus. [in Russian].

4. The Civil Rights Movement: A Cultural Revolution. (2014). Documentaries <https://www.memphis.edu/benhooks/documentaries/aculturalrevolution.php>. (2021, May, 28). [in English].

5. Encyclopedia Britannica (2021). Nina Simone <https://www.britannica.com/biography/Nina-Simone> (2021, May, 27). [in English].

\footnotetext{
${ }^{1}$ Encyclopedia Britannica (2021). Lorraine Hansberry <https://www.britannica.com/biography/Lorraine-Hansberry> (2021, травень, 27).

${ }^{2}$ Encyclopedia Britannica (2021). Amiri Baraka <https://www.britannica.com/biography/Amiri-Baraka>

(2021, травень, 27).

${ }^{3}$ Resnick, B., Hassler, A. (1958). Martin Luther King and the Montgomery Story

$<$ https://www.comics.org/issue/12536/> (2021, травень, 27).
} 
6. Encyclopedia Britannica (2021). Angela Davis <https://www.britannica.com/biography/Angela-Davis>. (2021, May, 27). [in English].

7. Denysova, T. N. (2012). Istoriia amerykanskoi literatury [History of the American literature]. Kyiv: VD Kyievo-Mohylianska akademiia. [in Ukrainian].

8. Rudwick, E. (2021). W.E.B. Du Bois. Encyclopedia Britannica <https://www.britannica.com/biography/W-E-B-Du-Bois>. (2021, May, 27). [in English].

9. King, M. L. Jr. (1963). Letter from Birmingham Jail <https://www.africa.upenn.edu/Articles_Gen/Letter_Birmingham.html>. (2021, May, 27).

10. King, M. L. Jr. (1964). Why We Can't Wait <https://kinginstitute.stanford.edu/encyclopedia/why-we-cant-wait>. (2021, May, 27). [in English].

11. Encyclopedia Britannica (2021). The Autobiography of Malcolm $X<\mathrm{https}$ ://www.britannica.com/topic/ The-Autobiography-of-Malcolm-X>. (2021, May, 27). [in English].

12. Encyclopedia Britannica (2021). Richard Wright <https://www.britannica.com/biography/Richard-WrightAmerican-writer $>$ (2021, May, 27). [in English].

13. Encyclopedia Britannica (2021). James Baldwin <https://www.britannica.com/biography/James-Baldwin> (2021, May, 27). [in English].

14. Encyclopedia Britannica (2021). Ralph Ellison <https://www.britannica.com/biography/Ralph-Ellison> (2021, May 27). [in English].

15. Encyclopedia Britannica (2021). Gwendolyn Brooks <https://www.britannica.com/biography/Gwendolyn-Brooks>. (2021, May, 27). [in English].

16. Encyclopedia Britannica (2021). Lorraine Hansberry <https://www.britannica.com/biography/Lorraine-Hansberry> (2021, May, 27). [in English].

17. Encyclopedia Britannica (2021). Amiri Baraka <https://www.britannica.com/biography/Amiri-Baraka> (2021, May, 27). [in English].

18. Resnick, B., Hassler, A. (1958). Martin Luther King and the Montgomery Story <https://www.comics.org/issue/12536/>. (2021, May, 27). [in English]. 